\title{
APLIKASI MOBILE UNTUK DETEKSI DAN KLASIFIKASI DAUN SECARA REAL TIME
}

\author{
Zaki Imaduddin ${ }^{1)}$, Hilmy Abidzar Tawakal ${ }^{2)}$ \\ 1), 2) Teknik Informatika Sekolah Tinggi Teknologi Terpadu Nurul Fikri \\ Kampus A, Sekolah Tinggi Teknologi Terpadu Nurul Fikri. Jl. Margonda Raya No. 522, Depok \\ Email:zaki_ip@yahoo.com. ${ }^{1)}$, hilmy@nurulfikri.com. ${ }^{2)}$
}

Penelitian ini diajukan untuk pendeteksian dan klasifikasi daun menggunakan sistem operasi android, dimana penelitian ini merupakan hasil pengembangan dari penelitian sebelumnya yang juga melakukan deteksi dan klasifikasi daun[1], pada eksperimen ini kami menggunakan 1.907 sample daun Flavia dimana 1335 daun untuk data pembelajaran dan 572 daun untuk data uji. Kami menggunakan 3 jenis daun yang berbeda untuk dideteksi dan diklasifikasi oleh sistem dimana ini belum ada penelitian yang melakukan proses deteksi dan pengenalan sekaligus dengan menggunakan objek daun. Kami menggunakan metode AdaBoost untuk mendeteksi daun dan kami menggunakan SVM untuk proses klasifikasi, sedangkan untuk ekstraksi fitur kami menggunakan haar like fitur dan LBP. hasil akurasi yang diperoleh dalam proses deteksi dan pengenalan dengan menggunakan mobile phone berbasis android ialah 66,91\%. Aplikasi ini sangat penting bagi masyarakat untuk sarana pembelajaran dalam mengetahui tiap jenis daun yang ada disekitar kita.

Kata Kunci: Android, AdaBoost, SVM, Haar Like Fitur, LBP

\section{PENDAHULUAN}

Indonesia adalah negara agraris yang terkenal akan kekayaan rempah rempah dan berbagai jenis tanaman. Dari dulu hingga sekarang tanaman herbal ataupun tanaman obat dapat menyembuhkan berbagai macam penyakit. Dari data yang berhasil dirangkum ternyata di indonesia sendiri terdapat lebih dari 38.000 spesies tumbuhan [2] yang tersebar diberbagai wilayah dan perhutanan indonesia.

Beberapa penelitian sebelumnya identifikasi tanaman sangat dibutuhkan dimana setiap bagiannya terdapat berbagai karakteristik yang mewakili tumbuhan tersebut, diantaranya adalah bentuk, warna dan tekstur [3]. Beberapa penelitian lain yang berhubungan dengan pengenalan jenis tumbuhan dengan mengidentifikasikan jenis daunnya juga telah banyak dilakukan Salah satunya ialah dengan Pendekatan dan metode yang digunakanpun berbeda-beda. Pada penelitian [4] daun diklasifikasikan berdasarkan ciri betuk (fitur morfologi), dan tekstur. Fitur morfologi yang menggunakan 5 basic fitur, sedangkan fitur tekstur didapatkan dengan menggunakan Gray-Level Co-occurrence Matrix (GLCM), kedua fitur tersebut digabungkan dengan menggunakan PNN. Dengan menggunakan dataset daun dari flavia, akurasi dari penggabungan dua metode tersebut menghasilkan nilai sebesar $93.0833 \%$

Beberapa penelitian tentang daun serupa dengan penelitian [4][5] yang juga menggunakan fitur morfologi dan tekstur, Penggunaan fitur morfologi untuk klasifikasi daun memberikan peningkatan pada tingkat akurasi. Namun penggunaan fitur tersebut juga memberikan beban komputasi tambahan yang membuat proses klasifikasi menjadi lebih lambat. Pada penelitian ini, jumlah fitur yang digunakan dibatasi untuk meningkatkan performa dari classifier, hal ini dilakukan untuk memudahkan sistem dijalankan pada perangkat bergerak dengan sumber daya terbatas (mobile devices).

Penelitian ini melanjutkan penelitian sebelumnya dimana sampai saat ini belum ada penelitian yang dapat mengenali beberapa jenis daun sekaligus, karena diharapkan hal ini dapat memberikan kontribusi ke depan mengenai pengenalan jenis daun langsung dari pohonnya secara realtime tanpa harus memetik atau merusak tanaman. deteksi dibutuhkan untuk memfokuskan atau mencari dimana letak daun berada dan mengenali jenis atau nama daunnya, sehingga benda-benda lain seperti batang atau serangga tidak menjadi halangan untuk proses pengenalan daun.

Penelitian ini menggunakan beberapa metode diantaranya ialah proses Ekstraksi Fitur dengan menggunakan metode Haar like Fitur kemudian metode Adaboost untuk mendeteksi keberadaan daun, metode Local Binary Pattern (LBP) untuk ekstaksi fitur dengan mengambil bentuk tekstur dari daun yang diubah kedalam bentuk histogram, dan untuk pengenalannya digunakan metode Support Vector Machine (SVM), dimana tiap daun diklasifikasi berdasarkan jenisnya.

Setelah objek daun terdeteksi proses selanjutnya adalah mengenali jenis daun. Proses pengenalan dilakukan dengan menggunakan fitur tekstur. Fitur tekstur pada daun dihitung dengan algoritma LBP (Local Binary Pattern). Classifier yang digunakan untuk melakukan proses klasifikasi adalah dengan SVM (Support Vector Machine). 


\begin{tabular}{|c|c|c|c|c|c|c|}
\hline Year & Author & Title & Dataset & Method & Classifier & Feature \\
\hline 2010 & Krishna Singh & $\begin{array}{l}\text { SVM-BDT PNN and Fourier Moment Technique } \\
\text { for Classification of Leaf Shape }\end{array}$ & Citra Daun & Klasifikasi & SVM-BDT PNN & $\begin{array}{l}\text { Morfologi,vein } \\
\text { Feature }\end{array}$ \\
\hline 2011 & A. Kadir & $\begin{array}{l}\text { Neural Network Application on Foliage Plant } \\
\text { Identification }\end{array}$ & Citra Daun & Segmentasi dan Identifkasi & Klasifier PNN & $\begin{array}{c}\text { shape, } \\
\text { vein, color, and } \\
\text { texture features }\end{array}$ \\
\hline 2013 & So fi ene Mouine & $\begin{array}{l}\text { A S hape-based Approach for Leaf Classification } \\
\text { using Multiscale Triangular Representation }\end{array}$ & Citra Daun & Klasifikasi & $\begin{array}{c}\text { Triangle Side } \\
\text { Lengths and Angle } \\
\text { Representation } \\
\text { (TSLA) }\end{array}$ & $\begin{array}{c}\text { Shape, texture and } \\
\text { color Feature }\end{array}$ \\
\hline 2013 & Yeni Herdiyeni & $\begin{array}{l}\text { A Computer Aided System For Tropical Leaf } \\
\text { Medicinal Plant Identification }\end{array}$ & Citra Daun & Identifikaksi & PNN+PDR & $\begin{array}{c}\text { morphology, shape } \\
\text { and texture } \\
\text { Feature }\end{array}$ \\
\hline 2014 & G.Karuna & $\begin{array}{l}\text { WaSS: A Novel Hybrid Method for Object } \\
\text { Recognition Using Wavelet based Statistical } \\
\text { and Structural Approaches }\end{array}$ & Citra Daun & Klasifikasi & Wass & Statistical features \\
\hline 2015 & Zaki I & $\begin{array}{l}\text { Deteksi dan Klasifikasi daun menggunakan } \\
\text { Metode Adaboost dan SVM }\end{array}$ & Citra Daun & Deteksi dan Klasifikasi & AdaBoost dan SVM & Tekstur \\
\hline 2015 & Zaki I & Aplikasi Mobile untuk Deteksi dan Klasifikasi daun & Citra Daun & $\begin{array}{c}\text { Deteksi dan Klasifikasi via } \\
\text { Mobile }\end{array}$ & AdaBoost dan SVM & Tekstur \\
\hline
\end{tabular}

Table 1. Penelitian terkait dan metode yang diusulkan

Penelitian ini menggunakan dataset flavia [6], Dimana tujuan utama dalam penelitian ini ialah sebagai sarana pembelajaran dalam hal pengenalan daun secara real time dengan menggunakan mobile phone. Seiring dengan banyaknya pengguna mobile phone maka penelitian ini juga menjadikan objek mobile phone dalam menerapkan sistem pendeteksi dan pengenalan pada beberapa jenis daun pada satu waktu.

\section{PEMBAHASAN}

Beberapa algoritma yang akan dibahas pada penelitian ini ialah Adaboost, sebagai metode untuk mendeteksi, SVM digunakan untuk metode klasifikasi, sedangkan untuk proses ekstraksi fitur digunakan dua metode yaitu Haar like fitur dan LBP. Beberapa penelitian tidak membahas mengenai deteksi dan pengenalan. berikut penjelasan mengenai beberapa metode yang digunakan.

\section{Adaptive Boosting (AdaBoost)}

AdaBoost atau biasa disebut dengan Adaptive Boosting, merupakan algoritma yang terdiri dari kumpulan weak classifier yang dibentuk menjadi strong classifier [7]. Adaboost diperkenalkan oleh Freund dan Schapire pada tahun 1995 [8]. Algoritma ini tersusun atas beberapa stage (classifier) yang ditiap stage tersebut terdapat fitur fitur yang sudah diseleksi berdasarkan error terkecil. Algoritma AdaBoost disusun dengan menggunakan persamaan dibawah ini:

Data citra diberikan label $(x 1, y 1), \ldots,\left(x_{n}, y_{n}\right)$ dimana $y_{i}=0,1$ untuk data negatif dan positif berturut-turut.

Untuk setiap citra training, diberi koordinat $(x, y)$ dengan $y=0$ untuk citra yang tidak mengandung object (citra negatif), dan $y=1$ untuk citra berisi object (citra positif).

Inisialisasikan bobot $w_{1, i}=\frac{1}{2 m}, \frac{1}{2 l}$ untuk $y_{i}=0,1$ berturut-turut, di mana $m$ dan $l$ adalah jumlah negatif dan positif berturut-turut.
Setiap citra diberi bobot awal yang sama, $\frac{1}{2 m}$ untuk citra negatif, dan $\frac{1}{21}$ untuk

citra positif. Di mana $\mathrm{m}$ adalah jumlah total citra negatif, dan 1 adalah jumlah total citra positif yang digunakan dalam proses training.

Untuk $t=1_{x \ldots s} T_{m}$

1. Normalisasikan bobot,

$w_{t, i} \leftarrow \frac{w_{t, i}}{\sum_{j=1}^{n} W_{t, j}}$

2. Untuk setiap fitur, $f$, latih sebuah classifier $h_{j}$ yang dibatasi agar menggunakan sebuah fitur tunggal. Kesalahan dievaluasi sehubungan dengan

$w_{t}, \epsilon_{j}=\sum_{i=1} w_{i}\left|h_{j}\left(x_{i}\right)-y_{i}\right|$

3. Pilih classifier, $h_{\mathrm{t}}$, dengan kesalahan terendah $E_{t}$.

4. Perbaharui bobot:

$w_{t+1, i}=w_{t, i} \beta_{t}^{1-\theta_{i}^{i}}$

dimana $e_{\mathrm{i}}=0$ jika data $x_{\hat{i}}$ diklasifikasi dengan benar, $\epsilon_{\mathrm{i}}=1$ jika sebaliknya, dan $\beta_{\mathrm{t}}=\frac{\epsilon_{\mathrm{t}}}{1-\varepsilon_{\mathrm{t}}}$.

Untuk menentukan satu classifier terbaik diperlukan beberapa iterasi perhitungan seperti menghitung error dan update bobot. Hasil perolehan fitur yang memiliki fitness function paling optimal atau error yang paling rendah maka dia yang akan masuk ke classifier pertama.

$H(x)=\operatorname{sign} \sum_{t=1}^{T} \alpha_{t} h_{t}(x)$

Hal ini dilakukan secara berulang selama iterasi tertentu hingga didapatkan weak classifier terpilih untuk menentukan keberadaan objek yang ditempatkan pada masing-masing stage yang telah terbentuk dengan metode AdaBoost. 


\section{Ekstraksi Fitur (Feature Extraction)}

Haar-like Feature merupakan metode ekstraksi fitur yang dalam penelitian ini digunakan untuk proses pencirian fitur tiap daun, dimana perhitungan pada dasarnya Haar fitur ialah menentukan nilai rata-rata dari sisi yang berwana putih dikurangi dengan nilai rata-rata dari sisi yang berwarna hitam. Berikut gambar haar like fitur yang digunakan:
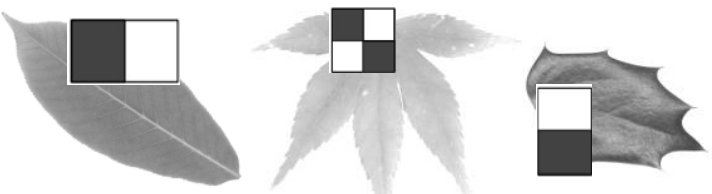

Gambar 1. Ekstraksi fitur daun dengan fitur Haar-like

namun dengan integral image maka proses perhitungan nilai dari tiap fitur akan lebih cepat [9]. Pada integral image di lokasi $\mathrm{x}, \mathrm{y}$ merupakan hasil penjumlahan dari posisi piksel mulai dari sebelah kiri atas. Berikut persamaanya.

$$
i x(x+y)=\sum_{x^{f} \leq x y^{f} \leq y} i\left(x^{s} y^{y}\right)
$$

Hasil dari deteksi daun menggunakan AdaBoost dan fitur Haar like dapat dilihat pada gambar 3 dibawah ini.

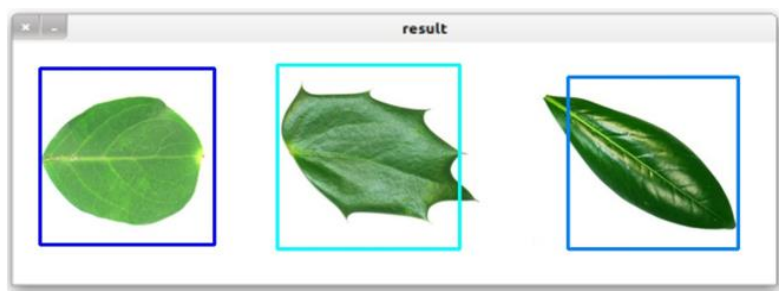

Gambar 2. Deteksi 3 jenis daun dalam 1 citra

Proses deteksi dengan Adaptive Boosting (AdaBoost)

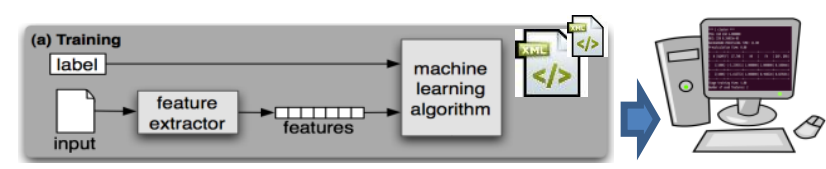

Gambar 3. Alur ekstraksi fitur dan deteksi dengan Haarlike dan AdaBoost

Berikut ini beberapa ketentuan untuk mendeteksi dan mengklasifikasikan daun dengan proses training dan testing, dimana hal tersebut dapat dilihat pada gambar 4 diatas, berikut penjelasannya:

Proses Training dan Testing:

1. Mengambil sampel daun sebesar $70 \%$ dari tiap spesies daun (total 1.335 daun) dari total keseluruhan daun sebanyak 1.907.

2. Ekstraksi fitur dilakukan dengan melibatkan ratusan ribu fitur dan ribuan nilai yang diambil menggunakan metode viola jones, namun perhitungan menjadi lebih cepat dengan menggunakan metode viola jones.

3. AdaBoost digunakan untuk menyeleksi setiap fitur dari hasil ekstraksi fitur, sehingga didapati fitur-fitur yang mewakili tiap jenis daun. Fitur tersebut di kumpulkan berdasarkan berdasarkan error terkecil dan treshold yang kemudian dikumpulkan kedalam bentuk cascade atau stage dengan jumlah stage tertentu.

4. Proses training/latih dan ekstraksi fitur juga dilakukan di dalam sistem mobile, dimana setiap daun juga dilakukan proses training dengan menggunakan SVM dan LBP, dimana setiap jenis daun di deteksi dan disimpan datanya lalu dilakukan proses training untuk dilakukan proses pengenalan daun via mobile.
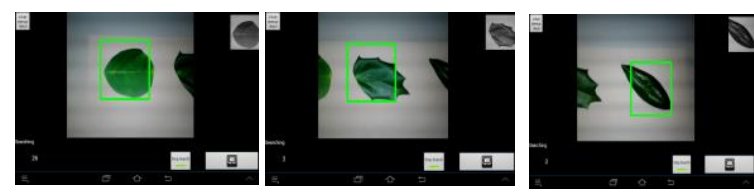

Gambar 4. Proses training via mobile

\section{Support Vector Machine}

Support Vector Machine (SVM) merupakan teknik klasifikasi yang masih relatif baru, teknik ini telah banyak digunakan oleh para peneliti untuk menyelesaikan permasalahan mengenai komputasi, dalam metode ini, kita berusaha untuk menentukan fungsi hiperplane atau klasifier terbaik antara fungsi yang tidak terbatas jumlahnya untuk memisahkan dua macam objek, Hyperplane terbaik adalah hyperplane yang terletak di tengah-tengah antara set objek dari dua kelas, mencari hyperplane terbaik ekuivalen dengan maksimal margin atau jarak antara dua objek dari kelas yang berbeda.

Support Vector Machine (SVM) merupakan metode yang digunakan untuk mengklasifikasikan data, dalam kasus ini, peneliti menggunakan SVM untuk melakukan pengenalan daun berdasarkan jenisnya. dibantu dengan metode ekstraksi fitur yaitu LBP, Local Binary Pattern merupakan metode texture deteksi yang digunakan untuk mengambil pola tekstur dari daun yang ubah menjadi bentuk histogram, dimana pola histogram yang dihasilkan dijadikan penciri dari tiap daun.

\section{HASIL EKSPERIMEN}

Penggabungan antara Metode adaboost dan SVM menghasilkan deteksi dan pengenalan daun, dimana kedua metode tersebut perlu dilengkapi dengan fitur ekstraksi untuk membantu pengenalan daunnya. Untuk tahapan awal dalam proses training dan ekstraksi fitur dilakukan di komputer dimana proses pembelajaran 
dilakukan menggunakan 1.335 daun yang terbagi menjadi 32 jenis untuk di ekstraksi tiap fiturnya menggunakan haar like fitur dan di seleksi berdasarkan error terkecil dan tresholdnya, setelah itu sistem mengubah hasil seleksi fitur ke dalam bentuk klasifierklasifer baru atau stage, dimana setiap stage mengandung fitur-fitur yang nantinya akan digunakan untuk mengetahui posisi dan mendeteksi daun. Setiap stage akan dikemas dalam sebuah file yang .xml, dimana file tersebut digunakan untuk proses pengenalan daun.

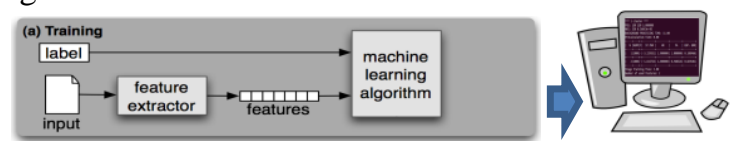

Gambar 5. Proses pembelajaran (Training)

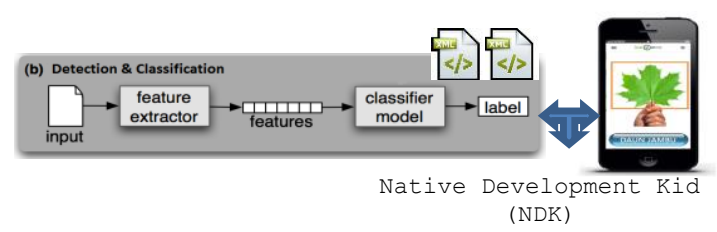

Gambar 6. Proses Klasifikasi

Untuk proses klasifikasi atau pengenalan daun dilakukan didalam sistem mobile, dimana setiap daun akan ditraining dan dikenali berdasarkan jenisnya. Didalam sistem mobil juga dilakukan proses ekstraksi fitur dengan menggunakan LBP, dan jumlah daun yang diekstraksi fiturnya tergantung dari hasil deteksi, atau dengan kata lain tergantung seberapa besar kemampuan file .xml untuk menghasilkan sistem deteksi daunnya, semakin banyak daun yang terdeteksi, maka semakin banyak pula daun yang dapat dikenali, Metode SVM menggunakan hasil Ekstraksi fitur dari LBP untuk mengklasifikasikan daun terhadap jenisnya.

Berdasarkan jenis daunnya melalui 3 citra daun yang berbeda didalam 1 gambar dan masing-masing sudah dibagi menjadi 136 kelompok citra daun, dengan menggunakan metode yang diusulkan pada paper ini, dari deteksi dan pengenalan daun menggunakan mobile menghasilkan akurasi sebesar 66,91\%. Contoh deteksi dan klasifikasi daun menggunakan mobile phone dapat dilihat pada gambar dibawah ini.

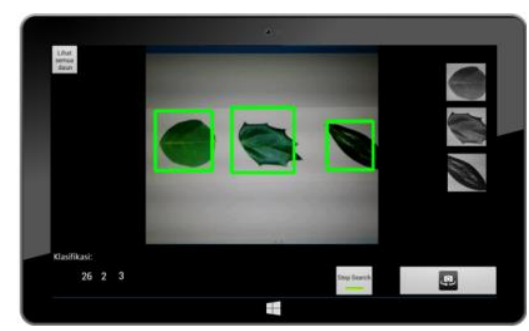

Gambar 7. Hasil Deteksi dan Klasifikasi via Mobile

\section{KESIMPULAN}

Penelitian ini bertujuan untuk mendeteksi dan melakukan pengenalan daun secara realtime, dimana pengembangan dari sistem ini diharapkan bisa menjadi sarana pembelajaran bagi masyarakat untuk mengetahui berbagai jenis tanaman secara realtime berdasarkan daunnya. Hasil penelitian yang didapat dari proses deteksi dan klasifikasi ini adalah dengan metode deteksi menggunakan metode AdaBoost menghasilkan akurasi sebesar 49,26\%, sedangkan dengan menggunakan metode Adaboost dan SVM dengan sistem mobile hasil akurasi yang didapatkan mencapai $66,91 \%$. Diperlukan pengembangan lebih lanjut untuk menghasilkan pengenalan daun yang lebih optimal.

\section{UCAPAN TERIMA KASIH}

Terimakasih yang sebesar-besarnya kepada tim riset mahasiswa STT Terpadu Nurul Fikri atas masukan dan dukungannya, dan juga kepada para donatur, sehingga penelitian ini bisa berjalan dengan baik.

\section{DAFTAR PUSTAKA}

[1] Z. Imaduddin, Hilmy A.T, "Deteksi dan Klasifikasi Daun Menggunakan Metode Adaboost dan SVM" In Proceeding of semnasteknomedia, pp. 3.2-43, 2015.

[2] Bappenas. 2003. Indonesia Biodiversity Strategy and Action Plan 2003-2020. Jakarta: Bappenas.

[3] Mouine Sofiene, Yahiaoui Itheri, Blondet Anne Verroust "A shape based approach for leaf classification using multiscale triangular representation" Third ACM International Conference on Multimedia Retrieval 2013.

[4] Kadir, A., Nugroho, L. E., Susanto, A., \& Santosa, P. I. (2011c). Neural network application on foliage plant identification.International Journal of Computer Applications, 29, 15-22

[5] Y. Herdiyeni et al., "A computer aided system for tropical leaf medicinal plant identification." IJASEIT, vol. 3, no. 1, pp. 23-27, 2013.

[6] S. Wu, F. Bao, E. Xu, Y.-X. Wang, Y.-F. Chang, and Q.-L. Xiang. A leaf recognition algorithm for plant classification using probabilistic neural network. In Signal Processing and Information Technology, 2007 IEEE International Symposium on, pages $11-16$, dec. 2007.

[7] Ruan, Q. Ruan, and X. Li, "Real Adaboost feature selection for Object Recognition," in IEEE 10th International Conference On Signal Processing Proceeding , pp. 1402-1405, 2010.

[8] Yoav Freund and Robert E. Schapire. A decisiontheoretic generalization of on-line learning and an application to boosting. Journal of Computer and System Sciences, 55(1):119.139, August 1997.

[9] Viola, Paul A. and Jones, Michael J. "Rapid Object Detection using a Boosted Cascade of Simple Features", IEEE CVPR, 2001. 